Monika Kavalir ${ }^{*}$

UDK 81'342.9:[811.111'367.623:811.163.6]

University of Ljubljana

DOI: 10.4312/linguistica.57.1.151-160

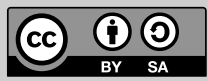

\title{
PROSODY AND ABSOLUTE VS. RELATIVE USES OF ENGLISH AND SLOVENE ADJECTIVES
}

\section{INTRODUCTION}

The paper takes inspiration from Rastislav Šuštaršič's work on the contrastive analysis of English and Slovenian (Šuštaršič/Kocijančič-Pokorn 1998; Kocijančič-Pokorn/ Šuštaršič 1999, 2001), and especially from his investigation into the differences and similarities between the two languages in terms of stress and accent (drawing primarily from his doctoral research as presented in Šuštaršič 1993, 1994, 1995). The concept of absolutely and relatively used adjectival structures in English and Slovene, presented in Section 2 and developed in Kavalir (2014), is investigated through the lens of prosody in the following sections, which focus on adjectival structures in the base (positive) degree, and the comparative and superlative degrees, respectively.

\section{ABSOLUTELY AND RELATIVELY USED ADJECTIVAL STRUCTURES}

The concept of absolutely and relatively used adjectival structures in English and Slovene brings together previously disparate ideas about the comparison and intensification of adjectives, proposing two parallel systems within the framework of Systemic Functional Linguistics (Kavalir 2014).

In both languages, adjectives (and adjectival structures) can be used in all three degrees, base (positive), comparative, and superlative, with reference to two different standards, internal and external. The subsystem of standard has at its core the question whether the meaning of the adjective depends crucially on the nominal referent (or some other external circumstance), yielding what is termed the relative use of adjectives, or whether the meaning of the adjective is contained within the adjectival structure, i.e. whether the adjective is used absolutely. The two options are a matter of use and not an inherent feature of adjectives, although some adjectives will be predominantly used with one standard rather than the other. For reasons which are beyond the scope of the present paper, the systems can be shown to pertain to the interpersonal metafunction in the Hallidayan theory of language.

Table 1 shows examples of all possible combinations for both English and Slovene. ${ }^{1}$ Semantically, the most important difference between relative (external standard) and absolute (internal standard) uses is the fact that relative uses do not entail the positive: when

* monika.kavalir@ff.uni-lj.si

1 Due to important distinctions in the strategies employed by the two languages, the examples of comparative and superlative degrees with an internal standard represent uses typical of each language rather than direct counterparts of each other. 
we say that she chose a nicer ring than he originally suggested, this does not entail that the ring was actually nice. Such an implicature can be struck down explicitly, e.g. She chose a nicer ring than he originally suggested, although it was still pretty darn ugly. ${ }^{2}$

Table 1: Adjectives in English and Slovene, according to degree and standard (Kavalir 2014)

\begin{tabular}{|c|c|c|c|}
\hline & Base degree & Comparative degree & Superlative degree \\
\hline $\begin{array}{l}\text { External } \\
\text { standard }\end{array}$ & $\begin{array}{l}\text { ENG: Mary has a big } \\
\text { dog. } \\
\text { SLO: Marija ima } \\
\text { velikega psa. }\end{array}$ & $\begin{array}{l}\text { ENG: She chose a } \\
\text { nicer/more extrava- } \\
\text { gant ring than he } \\
\text { originally suggested. } \\
\text { SLO: Izbrala je lepši/ } \\
\text { bolj ekstravaganten } \\
\text { prstan, kot ga je pred- } \\
\text { lagal on. }\end{array}$ & $\begin{array}{l}\text { ENG: Luxembourg is } \\
\text { the richest/most ad- } \\
\text { vanced EU country. } \\
\text { SLO: Luksemburg je } \\
\text { najbogatejša/najbolj } \\
\text { napredna država EU. }\end{array}$ \\
\hline $\begin{array}{l}\text { Internal } \\
\text { standard }\end{array}$ & $\begin{array}{l}\text { ENG: His grandfather } \\
\text { is a kind man. } \\
\text { SLO: Njen stari oče je } \\
\text { prijazen človek. }\end{array}$ & $\begin{array}{l}\text { ENG: All better hotels } \\
\text { offer self-service. } \\
\text { He explained some of } \\
\text { his more radical ideas } \\
\text { about the afterlife. } \\
\text { SLO: Vsi boljši hoteli } \\
\text { nudijo samopostrežne } \\
\text { obroke. } \\
\text { Njegove ideje o } \\
\text { posmrtnem življenju } \\
\text { so bolj temačne. }\end{array}$ & $\begin{array}{l}\text { ENG: Alan bought } \\
\text { her the cutest little } \\
\text { bouquet. } \\
\text { Alan bought her a/the } \\
\text { most wonderful little } \\
\text { bouquet. } \\
\text { SLo: To bom storila z } \\
\text { največjim veseljem. } \\
\text { Kupila je obleko iz } \\
\text { najbolj finega žameta. }\end{array}$ \\
\hline
\end{tabular}

In the case of absolute uses, entailment is present in all three degrees. In the comparative degree, the positive is present but modulated, yielding the meaning 'quite $x$,' and the superlative has an elative meaning 'very $x$ '. The shading in Table 1 also suggests that, although both uses are present in both languages, absolute comparatives are more productive in Slovene and absolute superlatives are considerably more productive in English. ${ }^{3}$

2 Implication can be strengthened or entailment added using various lexicogrammatical means, such as premodification by even/še (e.g. Catherine, made less thin by candlelight, had put on a blue dress which made her look even younger than her age; Na sliki imaš še lepšo frizuro kot $v$ resnici), comparative reduplication (e.g. Things got better and better between them as weeks passed), or using the non-neutral member of the antonymic adjectival pair specific to a dimension or noun related to so-called inherentness (e.g. Peter is the shorter of the two (neutral for size: tall); The red towel is a little bit wetter than the blue one (neutral for dryness: dry); $c f$. Cruse 1991: 214-222; Frazier/Clifton/Stolterfoht 2008).

3 Unfortunately, this research question does not lend itself well to corpus investigations, but Kavalir (2014) investigates it qualitatively and shows that, for instance, absolute comparatives in Slovene are so productive that they exhibit a specialization whereby synthetic comparison pairs up with positive evaluation, and analytic comparison with negative evaluation; no such significant tendencies have been observed in English. 
What is also obvious from Table 1 is that both kinds of comparison, synthetic (with -er and -est in English, and -ši and $n a j-+-\check{s} i$ in Slovene) as well as analytic (with more and most in English, and bolj and najbolj in Slovene), are possible with both absolute and relative uses. Kavalir (2014) has shown, however, that there is a link between these systems, and that corpus investigations (focusing on the construction " $X$ couldn't be more $Y / Y$-er," for instance) prove that absolute uses feature analytic patterns significantly more frequently compared to their distribution in general. While this is an important morphosyntactic reflex of the semantic difference between absolute and relative uses, this paper shows how this grammatical phenomenon interacts with prosody.

\section{THE PROSODY OF ADJECTIVAL STRUCTURES IN THE BASE DEGREE}

In the base degree (usually called the positive, but the term is avoided here to ensure clarity), there is only one form, so even if it can be shown that absolute and relative uses have an effect on the type of comparison in the comparative and superlative degrees, this does not in any way prove that the distinction is justified in the base degree as well. Halliday's take (1998/1985: xx) on Occam's razor is very much applicable here:

[A]ll the categories employed must be 'there' in the grammar of the language. They are not set up simply to label differences in meaning. In other words, we do not argue: 'these two sets of examples differ in meaning; therefore they must be systematically distinct in the grammar'. They may be; but if there is no lexicogrammatical reflex of the distinction, they are not.

Syntactically, there appears to be some link to the position of the adjective. Let us consider English first. When an adjective is used predicatively, the fact that it is more distant from the referent noun can promote an absolute interpretation, and the proximity of the referent noun in attributive use increases the likelihood of a relative (scalar) interpretation. If the sentences He's a clever dog, isn't he? and I never realized our dog was so clever! are compared, attributive use of the adjective clever means it is more likely to be interpreted relatively as 'intelligent compared to other dogs,' while predicative use makes us think the dog is 'absolutely smart'. ${ }^{4}$ This is by no means universally true, and sentences like It's a big universe and That puppy is still very small are good examples of combinations attributive + absolute and predicative + relative.

It is prosody, therefore, that provides the strongest evidence that a grammatical distinction between absolute and relative uses in the base degree is indeed justified. As mentioned before, both kinds of uses combine with both adjectival positions, attributive and predicative, but what changes the situation is if the adjective becomes the focus of the intonation unit: putting tonic stress on the adjective and prolonging the vowel restricts the interpretation to an absolute one, e.g. There was a BIG cat. While the context of interaction may prioritize other factors and yield other options in terms of neutral

4 Possibly 'so smart he can be compared to a human,' as the internal standard often seems to be anthropocentric. 
and marked tonicity ( $c f$. Halliday 1967, 2005), what is at the core of the argument here is that it is indeed possible for prosody to do away with the inherent structural ambiguity present in such constructions.

The use of the above-mentioned prosodic cues is crucial especially when the more likely interpretation would be a relative one, with adjectives of size, which tend to be scalar and describe a nominal referent with reference to other members of the same category, e.g. There was a big CAT. It was BIG. It is worth noting that saying the same of a grain or a flea would only be acceptable in two cases: (i) if the grain/flea really is big in terms of internal standard, i.e. from the point of view of humans; or (ii) if the speaker suggests this as a hyperbole - in this case the addressee knows (i) is impossible and infers that the referent was extremely big compared to other members of the same group. What is important, though, is that in the later case the process is not straightforward going from 'for grains/fleas, this is a large one; actually, for grains/ fleas, this is a very large one,' but passes through a stage where the addressee recognizes that the speaker is relating the size of the grain/flea to human standards and expressing an exaggeration.

This mechanism can be related to Cruse's (1991: 217) account of "prosodic gradation" in "implicit superlatives", i.e. adjectives which do not exhibit the category of comparison: "[A]lthough [implicit superlatives] cannot be lexically or morphologically graded, they can be prosodically graded, that is to say by means of stress and intonation [...] Thus, the 'hugeness' of something can be indicated by the pitch range of the falling tone on huge in It's hùge!"

These patterns show that the matter of absolute vs. relative uses of adjectives in the base degree goes beyond semantics. The same prosodic tools do not work with merely semantic phenomena, and placing the focus of intonation on an ambiguous lexeme with several possible meanings cannot elucidate the intended interpretation, so that emphasizing It was a CRANE cannot make it clear whether the crane mentioned was a bird or a machine.

Finally, it is an interesting question why, in examples like the ones above, a focus on the adjective should yield the absolute interpretation rather than a relative one. While this is hardly an empirical issue, it can be hypothesized that placing the focus on the adjective automatically relegates the noun to less prominence in the prosodic hierarchy. Brazil (1997/1985: 18) states that "[t]he allocation of prominence to a word can be shown to be consistently the result of a speaker-decision over and above that which resulted in the choice of the particular lexical item. It is, therefore, independently meaningful." When intonation cues suggest the nominal referent is less important, it is not difficult to imagine that the interpretation will obviate it as well.

There is nothing in these suggestions that would tie them to a particular language, and indeed it turns out that Slovene adjectival structures in the base degree function in exactly the same way as in English. The two languages are therefore a very good match in this area, with both absolute and relative uses possible ( $c f$. Table 1), and with the possibility of using prosody to bring absolute interpretations to the foreground (e.g. Imela je VELIKEGA psa with the same characteristics as She had a BIG dog). 


\section{THE PROSODY OF COMPARATIVE AND SUPERLATIVE ADJECTIVAL STRUCTURES}

When it comes to comparative and superlative adjectival structures, synthetic comparison by means of comparative inflections -er and -est as well as -ši and naj- + -ši does not allow for any choice when it comes to word stress, which must obligatorily fall on the lexical morpheme. Mondorf (2003) claims that the cause-consequence relationship here might be reversed, arguing that when the word that follows begins with an initial stressed syllable, preference is normally given to synthetic comparison as opposed to analytic comparison, with the affixes -er and -est used to establish a 'buffer' between the stresses, e.g. a fresher salad vs. a more fresh salad. Hilpert's (2008) quantitative analysis of suggested factors on the choice of comparison in the British National Corpus (using only adjectives that are attested with both kinds of comparison) did not show this circumstance to have a significant impact on the type of comparison.

The situation is very different when it comes to adjectival structures exhibiting analytic comparison. Many authors (e.g. Biber et al. 2000: 522) suggest the choice of analytic rather than synthetic comparison in English can be conditioned by the desire to stress the comparison for emphatic reasons. Making the words more or most prominent (i.e. accented) thus does away with structural ambiguity and singles out the relative interpretation as the only one applicable, or in Curme's (1931: 504) words, speakers "stress the more or most when we desire to emphasize the idea of degree: 'She is indeed béautiful, but her sister is still móre beautiful." The same reasoning is again valid in the case of Slovene: Tina je BOLJ inteligentna od sestre.

There is, however, an important difference between the two languages in how the extent to which more (bolj) and most (najbolj) are stressed in connected speech affects the interpretation. In general, the literature reports similar findings for degrees of stress in both languages. Šuštaršič (1993: 118ff; 1995: 159ff) adapts Varga's (1975; also related to Kingdon 1966/1958: 8; O'Connor/Arnold 1973; Wells 2007/2006: 228-229) system of four degrees of stress, and finds that it described both English and Slovene well. The four categories he distinguishes are:

1. Syllables with primary stress - syllables with primary stress are the only ones that can be dynamically accented.

2. Syllables with secondary stress - the vowel in such a syllable is a strong, loud and long one compared to unstressed syllables, but when following the primary stress, the syllable does not have tonic prominence.

3. Syllables with tertiary stress - the vowel in such a syllable is a strong one, somewhat louder and longer compared to unstressed syllables, but the syllable does not have tonic prominence even in a position before the primary stress.

4. Unstressed syllables - pronounced with minimal volume; in English, they mostly contain vowels of centralized and reduced quality. 
The difference in unstressed syllables is discussed as follows in Collins, Šuštaršič and $\operatorname{Komar}$ (2014: 100-101): ${ }^{5}$

It has been claimed that English, as well as some other European languages, are stress-timed. This means that sentence stresses seem to occur at roughly regular intervals in connected speech. To achieve this stress-timed rhythm, unstressed syllables are shorter, while their 'full' vowels are usually replaced by $/ \mathrm{\partial} /, \mathrm{I} / \mathrm{or} / \mathrm{U} /$. Since the occurrence of stressed syllables remains regular, i.e. at more or less equal intervals, the reduced unstressed syllables can be squeezed in between the stressed ones.

\author{
They BOUGHT a CAR. \\ They BOUGHT a NEW CAR. \\ They've just BOUGHT the FASTest SPORTS car. \\ They've just BOUGHT the very FASTest and MOST expensive SPORTS car.
}

Other languages, including Slovene, are considered to be syllable-timed. In these languages the length of stressed and unstressed syllables remains roughly the same (i.e. unstressed syllables are not noticeably reduced) and the vowel quality of unstressed syllables is maintained.

While stress is of course not a discrete variable and "innumerable gradations of stress" (Kingdon 1966/1958: 8) could be distinguished if desirable, ${ }^{6}$ Šuštaršič's account is detailed enough to point out a number of differences in the degree of stress for various constructions in English and Slovene. Although not discussed at length in his work, the general conclusion that can be drawn ( $c f$. Cruttenden 1997: 17-18, 44; Komar 2008: 19, 113-114; Ladefoged 2001: 91-93) is that many elements that are unstressed in English tend to receive some degree of stress in Slovene. Some of Šuštaršič's examples comprise, for instance, demonstratives (e.g. these people vs. ti ljudje with tertiary stress on these and secondary stress on $t$ ), greetings (e.g. good morning, with no stress on good, vs. dobro jutro, where dobro can receive anything between secondary and no stress), and some constructions where the English version allows unstressed syllables but the Slovene does not (e.g. titles - Mr Smith vs. gospod Smith; pronouns preceding emphatic reflexives - I myself vs. jaz sam). ${ }^{7}$

5 This of course has important implications for Slovene-produced English, where connected speech phenomena such as loss of stress and vowel reduction are missing. The same tendencies have been noticed in L2 English speakers coming from several different languages (although Sönning (2014) surprisingly reports no significant differences in terms of vowel reduction in German L2 speakers of English) but they cannot be generalized to all Slavic languages as Russian, for instance, has been shown to produce exactly the opposite transfer effects with speakers lacking secondary stress and over-reducing unstressed vowels in English (Banzina/Dilley/Hewitt 2016).

$6 C f$. Brazil (1997/1985: 18) for a critique suggesting only primary and secondary stress are useful in the identification of "meaningful contrasts."

7 What Šuštaršič $(1993,1995)$ himself notes in his experimental work is that realizations may vary across different speakers of the same language, and as one of the reviewers suggests, good in good morning may actually be both stressed and accented. 
On a side note, a tendency that, according to Šuštaršič (1993: 142; 1994: 34; 1995 : 174), causes many differences between the two languages in the realisation of intonation is the fact that in English the last lexical item in the intonation unit will usually be the focus, whereas Slovene will often have the focus prior to the last lexical item. As it happens, synthetic comparatives are a typical example of this and Šuštaršič (1993: 127; 1995: 165) points out in particular that in cases like I still think his car is better than MINE vs. Še vedno mislim, da je njegov avto BOLJŠI od mojega it is often more appropriate in Slovene to place the primary stress on the adjective - so it could well be that in Slovene intonation patterns contribute to the link between relative uses and synthetic comparison.

What can be observed is that in both English and Slovene the independent morphemes more, most, and bolj (absolute superlatives are so rare in Slovene that it is difficult to produce judgements for najbolj) will generally be unstressed and often reduced in absolute uses (for Slovene already noted in Toporišič 2004/2000: 327; cf. Tomšič 1956/1957: 123). Some examples from the spoken part of the BNC corpus and GOS, the corpus of spoken Slovene, testify to this:

\author{
I've TAKen one of the more OBvious ones \\ the more ausTERE TYPES \\ of the more proGREssive ones \\ bl slaBU JE za JEST \\ k ponaVAD je v BISTvu bl brezPLAČno ne \\ TU je bl težKU no
}

The crucial distinction is, however, that in Slovene the difference between the more or less stressed relative bolj and the unstressed absolute bolj is very salient, so that loss of stress guides the addressee to favour an absolute interpretation. It is important to point out, of course, that prosody is a matter of spoken language and the context of interaction will include many additional factors that may prevail over this lexicogrammatical consideration.

In English, on the other hand, it is quite common for the relatively used more and most to be unstressed as well (e.g. Lecumberri/Maidment 2000: 83, 90, 95), which means that the difference in prosodic prominence does not have the same power of differentiating meanings as in Slovene. Following the spirit of Brazil's (1997/1985) work on the role of speaker-decision and meaningful contrasts expressed through prosody, it could be said that the contrast presented by the Slovene speaker not allocating prominence to the comparative adjective is in some ways more meaningful than the one presented by the English speaker.

It would go beyond the scope of this paper to attempt a diachronic investigation into the development of absolute and relative adjectival uses and their prosodic patterns, but the synchronic characteristics of these constructions suggest the current state of affairs might be related to the process of subjectivisation/subjectification in language, which would postulate the evolution of absolute uses from relative ones. In this respect it may 
be of interest that early literature on the development of intensification (e.g. Stoffel 1901 in Traugott 2006: 335 for adjective-intensifying adverbs) already mentions some typical, and not unfamiliar, prosodic traits of such semantic change, for instance when it comes to modalised subjective uses and a reduction of stress.

\section{CONCLUSION}

The paper builds on Rastislav Šuštaršič's seminal work on the contrastive analysis of English and Slovene, especially in the field of their prosodic patterns, and applies it to the notion of absolute and relative uses of adjectival structures. It turns out that, in the base degree, intonation works in the same way in both languages and can perform the function of disambiguating between the two sets of interpretations. In the comparative and superlative degrees, however, the well-established difference in the intonation patterns of stress-timed English, which often resorts to stress reduction in connected speech, and syllable-timed Slovene, where word stress is rarely completely lost, results in important distinctions in how intonation interacts with absolute and relative uses. These findings, however, are only preliminary and clearly show a need for further research in this area, presumably involving experimental work and specially designed comparable spoken corpora.

\section{References}

BANZINA, Elina/Laura C. DILLEY/Lynne E. HEWITT (2016) “The role of secondary-stressed and unstressed-unreduced syllables in word recognition: Acoustic and perceptual studies with Russian learners of English." Journal of Psycholinguistic Research 45/4, 813-831. http://dx.doi.org/10.1007/s10936-015-9377-z

BIBER, Douglas/Stig JOHANSSON/Geoffrey LEECH/Susan CONRAD/Edward FINEGAN (2000) Longman Grammar of Spoken and Written English. Harlow: Longman.

BRAZIL, David (1997/1985) The Communicative Value of Intonation in English. Cambridge: Cambridge University Press.

COLLINS, Beverley/Rastislav ŠUŠTARŠIČ/Smiljana KOMAR (2014) PresentDay English Pronunciation. A Guide for Slovene Students. Revised and enlarged 2nd edition. Ljubljana: Filozofska fakulteta, Oddelek za anglistiko in amerikanistiko.

CRUSE, Alan D. (1991) Lexical Semantics. Cambridge: Cambridge University Press. CRUTTENDEN, Alan ( $\left.{ }^{2} 1997\right)$ Intonation. Cambridge: Cambridge University Press.

CURME, George O. (1931) A Grammar of the English Language in Three Volumes. Volume III: Syntax. Boston: D. C. Heath and Company.

FRAZIER, Lyn/Charles CLIFTON Jr/Britta STOLTERFOHT (2008) "Scale structure: Processing minimum standard and maximum standard scalar adjectives," Cognition 106: 299-324. http://dx.doi.org/10.1016/j.cognition.2007.02.004

HALLIDAY, Michael A. K. (1967) Intonation and Grammar in British English. The Hague/Paris: Mouton. 
HALLIDAY, Michael A. K. ( $\left.{ }^{2} 1998 / 1985\right)$ An Introduction to Functional Grammar. London: Arnold.

HALLIDAY, Michael A. K. (2005/1985) "English intonation as a resource for discourse." In: J. E. Clark (ed.), The Cultivated Australian: Festschrift in Honour of Arthur Delbridge. Beiträge zur Phonetik und Linguistik 48. Hamburg: Helmut Buske Publishers, 11-117.

HILPERT, Martin (2008) "The English comparative - language structure and language use." English Language and Linguistics 12/3, 395-417. http://dx.doi.org/10.1017/ S1360674308002694

KAVALIR, Monika (2014) Skladenjske in pomenske razsežnosti pridevniških zgradb. Doctoral dissertation. Ljubljana: Filozofska fakulteta Univerze v Ljubljani.

KINGDON, Roger (1966/1958) The Groundwork of English Stress. London: Longmans.

KOMAR, Smiljana (2008) Communicative Functions of Intonation: English-Slovene Contrastive Analysis. Ljubljana: Znanstvenoraziskovalni inštitut Filozofske fakultete.

KOCIJANČIČ-POKORN, Nike/Rastislav ŠUŠTARŠIČ (1999) "Slovensko-angleška protistavna analiza nedoločnika v vlogi premega predmeta." Vestnik 33/1-2, 267-281.

KOCIJANČIČ-POKORN, Nike/Rastislav ŠUŠTARŠIČ (2001) "Slovensko-angleška protistavna analiza nedoločnika v vlogi osebkovega oz. povedkovega določila." Slovenski jezik - Slovene linguistic studies 3, 32-41.

LADEFOGED, Peter ( $\left.{ }^{4} 2001\right)$ A Course in Phonetics. Fort Worth: Harcourt College Publishers.

LECUMBERRI, M. Luisa/John A. MAIDMENT (2000) English Transcription Course. London: Arnold.

MONDORF, Britta (2003) "Support for more-support.” In: G. Rohdenburg/B. Mondorf (eds), Determinants of Grammatical Variation in English. Berlin: Mouton de Gruyter, 251-304.

O'CONNOR, J. D./G. F. ARNOLD (21973/1961) Intonation of Colloquial English: A Practical Handbook. London: Longman.

SÖNNING, Lukas (2014) "Unstressed vowels in German Learner English: An instrumental study." Research in Language 12/2, 163-173. http://dx.doi.org/10.2478/ rela-2014-0001

ŠUŠTARŠIČ, Rastislav (1993) Kontrastivna analiza angleške in slovenske stavčne intonacije. Doctoral dissertation. Ljubljana: Filozofska fakulteta Univerze v Ljubljani.

ŠUŠTARŠIČ, Rastislav (1994) "Kontrastivna analiza angleške in slovenske stavčne intonacije." Vestnik 28/1-2,31-47.

ŠUŠTARŠIČ, Rastislav (1995) "Naglas in poudarek v angleščini in slovenščini." Slavistična revija 43/2, 157-182.

ŠUŠTARŠIČ, Rastislav/Nike KOCIJANČIČC-POKORN (1998) "Slovensko-angleška protistavna analiza angleškega nedoločnika v funkciji osebka." Vestnik 32/1-2, 299-320.

TOMŠIČ, France (1956/1957) “Stopnjevanje.” Jezik in slovstvo 2/3, 123-125. 
TOPORIŠIČ, Jože ( $\left.{ }^{4} 2004 / 2000\right)$ Slovenska slovnica. Maribor: Obzorja.

TRAUGOTT, Elizabeth C. (2006) "The semantic development of scalar focus modifiers." In: A. van Kemenade/B. Los (eds), The Handbook of the History of English. Oxford: Blackwell. 335-359.

WELLS, J. C. (2007/2006) English Intonation. An Introduction. Cambridge: Cambridge University Press.

\section{Abstract \\ PROSODY AND ABSOLUTE VS. RELATIVE USES OF ENGLISH AND SLOVENE ADJECTIVES}

The paper explores the role prosody plays in distinguishing two types of uses of adjectival structures in English and Slovene. In both languages, adjectival structures can be used with an internal standard, yielding an absolute interpretation, or with an external standard (typically comparing the nominal referent to other members of the same category), giving rise to a relative interpretation. It is shown that, in the base degree, a focus on the adjective provides disambiguation by making it clear that the construction is an instance of absolute use. In the comparative and superlative degrees, however, structural differences in the intonation patterns of the two languages come into play in the case of analytic comparison, so that in Slovene reduction in stress signifies absolute use, but in English relatively used comparatives and superlatives can be unstressed as well.

Keywords: adjectives, English, intonation, prosody, Slovene

Povzetek

\section{PROZODIJA TER ABSOLUTNA IN RELATIVNA RABA PRIDEVNIKOV V ANGLEŠČINI IN SLOVENŠČINI}

V prispevku analiziramo vlogo, ki jo prozodija igra pri razlikovanju med dvema tipoma pridevniških rab $\mathrm{v}$ angleščini in slovenščini. $\mathrm{V}$ obeh jezikih lahko pridevniške zgradbe uporabljamo z notranjim standardom, kjer se razvije absolutna interpretacija, ali z zunanjim standardom (tu gre tipično za primerjavo samostalniškega referenta $\mathrm{z}$ drugimi primerki iste kategorije), kjer pa pride do relativne interpretacije. Članek pokaže, da pri osnovni stopnji poudarek na pridevniku omeji interpretacijo, tako da je takšna zgradba lahko samo primer absolutne rabe. $V$ primerniških in presežniških zgradbah pa se po drugi strani strukturne razlike med intonacijskimi vzorci obeh jezikov pokažejo za pomembne $\mathrm{v}$ primeru opisnega stopnjevanja, saj v slovenščini nenaglašenost kaže na absolutno rabo, medtem ko so lahko $\mathrm{v}$ angleščini nenaglašeni tudi relativno rabljeni primerniki in presežniki.

Ključne besede: pridevniki, angleščina, intonacija, prozodija, slovenščina 